Abstracta Iranica Abstracta Iranica

Revue bibliographique pour le domaine irano-aryen

Volume 24 | 2003

Comptes rendus des publications de 2001

\title{
« La sculpture susienne à l'époque de l'empire parthe ». IA XXXVI, (2001), pp. 239-291.
}

\section{Rémy Boucharlat}

\section{Q OpenEdition \\ 1 Journals}

Édition électronique

URL : http://journals.openedition.org/abstractairanica/34346

ISSN : 1961-960X

\section{Éditeur :}

CNRS (UMR 7528 Mondes iraniens et indiens), Éditions de l'IFRI

\section{Édition imprimée}

Date de publication : 15 mai 2003

ISSN : 0240-8910

\section{Référence électronique}

Rémy Boucharlat, « « La sculpture susienne à l'époque de l'empire parthe ». IA XXXVI, (2001),

pp. 239-291. », Abstracta Iranica [En ligne], Volume 24 | 2003, document 84, mis en ligne le 05 janvier 2010, consulté le 25 septembre 2020. URL : http://journals.openedition.org/abstractairanica/34346

Ce document a été généré automatiquement le 25 septembre 2020.

Tous droits réservés 


\title{
« La sculpture susienne à l'époque de l'empire parthe ». IA XXXVI, (2001), pp. 239-291.
}

\author{
Rémy Boucharlat
}

Sous la forme d'un article, P.A. donne en fait la publication de la sculpture en pierre de Suse aux époques séleucide et parthe. Pour ne pas différer plus longtemps cette étude qu'il avait confiée à d'autres, P.A. a décidé de la faire lui-même. Les œuvres présentées ici ne sont pas des chefs-d'œuvre et, pour beaucoup d'entre elles, trouvées dans les fouilles anciennes de Suse, le contexte archéologique est très imprécis. Sur ce dernier point, l'A. livre le maximum d'information grâce à sa grande familiarité avec le site de Suse. Des objets eux-mêmes, il montre qu'ils constituent une intéressante illustration de l'histoire de Suse au cours de ces quelques cinq siècles: une cité grecque, d'extension limitée par rapport à la ville locale (mais les inscriptions grecques et certaines séries de figurines montrent que la population hellénisée n'était pas quantité négligeable); une ville hellénisée importante dans l'empire parthe, bénéficiant toujours de son statut de cité ; enfin une ville attirée dans la mouvance de l'Élymaïde, région à plusieurs reprises autonome dans la seconde partie de l'empire parthe.

\section{INDEX}

Thèmes : 3.2.3. Séleucides, Parthes et Sassanides 
AUTEURS

RÉMY BOUCHARLAT

CNRS - Lyon 